DIGITAL COMMONS
@ UNIVERSITY OF SOUTH FLORIDA

Volume 11

Issue 1 Summer 2021

\section{ABO: Interactive Journal for \\ Women in the Arts, 1640-1830}

\title{
Review of Eighteenth-Century Women's Writing and the Methodist Media Revolution, by Andrew O. Winckles
}

\author{
Rebecca Nesvet \\ University of Wisconsin, Green Bay, nesvetr@uwgb.edu
}

Follow this and additional works at: https://digitalcommons.usf.edu/abo

Part of the Dramatic Literature, Criticism and Theory Commons, Educational Methods Commons, Feminist, Gender, and Sexuality Studies Commons, and the Literature in English, British Isles Commons

\section{Recommended Citation}

Nesvet, Rebecca (2021) "Review of Eighteenth-Century Women's Writing and the Methodist Media Revolution, by Andrew O. Winckles," ABO: Interactive Journal for Women in the Arts, 1640-1830: Vol.11: Iss.1, Article 21. http://doi.org/10.5038/2157-7129.11.1.1254

Available at: https://digitalcommons.usf.edu/abo/vol11/iss1/21

This Reviews is brought to you for free and open access by Digital Commons @ University of South Florida. It has been accepted for inclusion in ABO: Interactive Journal for Women in the Arts, 1640-1830 by an authorized administrator of Digital Commons @ University of South Florida. For more information, please contact digitalcommons@usf.edu. 


\section{Review of Eighteenth-Century Women's Writing and the Methodist Media Revolution, by Andrew 0. Winckles}

\section{Keywords}

women, Methodism, media, Sarah Crosby, Sarah Wesley, John Wesley, manuscript culture, Romanticism, religion, Christianity

\section{Creative Commons License}

(c) (1) \&

This work is licensed under a Creative Commons Attribution-Noncommercial 4.0 License 
Andrew O. Winckles. Eighteenth-Century Women's Writing and the Methodist Media Revolution: “Consider the Lord as Ever Present Reader. ” Liverpool University Press, 2019. 272 pp. ISBN: 9781789620184

Reviewed by Rebecca Nesvet University of Wisconsin, Green Bay

As Deanna P. Koretsky proposed seven years ago in "Sarah Wesley, British Methodism, and the Feminist Question, Again" (Eighteenth-Century Studies, vol. 46, no. 2, Winter 2013), Sarah "Sally" Wesley, the daughter of Charles Wesley, co-founder of Methodism, was not only an artist with a sense of humor but a "rebel" whose intellectual activity partly "led to the emergence of liberal feminism," putting her alongside her contemporary Mary Wollstonecraft in that significant endeavor. Koretsky found this revolutionary activity in Wesley's unpublished manuscripts and cracked open a door in the history of both Methodism and Feminism. In the monograph Eighteenth-Century Women's Writing and the Methodist Media Revolution: "Consider the Lord as Ever Present Reader," Andrew O. Winckles acknowledges Koretsky's pioneering and takes her discovery quite a bit further. Methodism, Winckles claims, was a "media revolution." Primarily via manuscript culture and theologically influenced ideas about literary intention, audience, and affect that are alien to mainstream Romanticism, Methodist women virtually created a feminist media culture for the first time in the history of English letters. It is refreshing to note that this media revolution not only uplifted the women who engaged in it but also crossed class lines. Largely, it was a plebeian women's media movement - and an influential corner of Romanticism. Winckles's study is essential reading to scholars not only of feminism, eighteenth-century women's writing, and Methodism, but of working-class, coterie — kinship-group — writing, media history, manuscript studies, and Romanticism. The volume is defined by Methodist women's storied enthusiasm and the controversy that surrounded it, but also by Winckles's own enthusiasm for his subject and its transformative effects in the eighteenth century and potential in our own time. Like the Methodists' enthusiasm, at least in establishment lore, Winckles's is contagious.

He begins by quoting a screed from Robert Southey, Poet Laureate from 1813-43, and quintessential reactionary of the Romantic era. The writer whom Byron savagely satirized found Methodism too radical for his comfort. In his 1820 biography of Methodism's founder, John Wesley, Southey rails against what he called the "democratizing tendency of Methodist practice" (qtd. in Winckles 1). Unpacking this "tendency," which he agrees was actual, Winckles demonstrates 
that eighteenth-century Methodist evangelicalism not only aimed at a truly democratic reform of the Church of England that gradually became a revolution, but that this was "fundamentally a media revolution" not inherently opposed to "Enlightenment," but part of it (3). From the acceptance of women and men of non-elite education as preachers and witnesses, to the democratic "unbounded space of the field meeting"- the ecclesiastical equivalent of common grazing land, Methodism was from its origins an attempt to transfer agency, creativity, and authority in religious matters to the people, broadly defined (9). Field meetings frightened authorities in ways that eerily anticipate the Peterloo Massacre of 1819 . Winckles moves on to show that the media revolution was most creatively advanced by Methodist women. As he argues:

By focusing on how Methodist women adapted to the shifting rhetorical culture of Methodism we can thus gain a better perspective on the broader shifts going on in British life and culture and especially some of the ways women writers adapted to rapidly shifting social, cultural and religious expectations surrounding womanhood and femininity. (13)

In the first chapter proper, Winckles demonstrates how the eighteenth-century Methodism which John Wesley's growing flock practiced in his lifetime was both Romantic and a media revolution via field meetings, deliberate usage of "the language of common life" long before Wordsworth linked it with formal, published, verse poetry, and the "provi[sion] of a public space for men and women of all walks of life to speak publicly and to participate in religious" experience and discourse (43). Women contributed to this revolution largely not through print, but in a vivid manuscript culture that prioritized copying, circulation, discussion, and revision of theological and life writings (62). Winckles illustrates this theory with many memorable and persuasive examples. One of the most poignant figures he surveys is Sarah Mallit Boyce, one of the first women preachers (69). The revolution to which she contributed opened the Republic of Letters not only to women but to working-class writers, storytellers, and rhetoricians.

Winckles's second chapter dramatically alters the critical landscape surrounding a very canonical heroine: Samuel Richardson's Pamela. Winckles contextualizes Pamela (1740) by tracing Richardson's encounters with Methodism and also performing a rhetorical analysis of Methodist women's correspondence, which, as he shows, was not really private, but constituted self-discovery, confession, social expose, and communion with other Methodists (including top leaders), and with the divine. Much of this made its way into Pamela's - and Pamela's - use of the 
epistolary medium. This is the book's most illuminating chapter on account of its provision of an eclectic "composite" of several Methodist women's letters from the archives, which is informative, arresting, and reads like a nearly seamless dramatic monologue. Methodologically, Winckles's construction of this composite letter is unusual, and perhaps unprecedented. However, the approach reveals how such letters operated as a genre much better than sparse quotation of many of them would have done, and he documents the seams in the patchwork with clarity and rigor. One woman, intriguingly, divulges that, worn down by endless cycles of childbirth and child-raising, she investigated some kind of pharmaceutical abortion (90). This and other details of the composite letter will prove very useful not only to researchers of eighteenth-century British women's lives but pedagogically as well. Pamela is at her most Methodist when she promises to "set about a Reformation" within her household — of her social superior, a powerful man (qtd. in Winckles 105). That makes her Reformationand that of the Methodist women who served as her model-ground-breaking.

The third chapter exposes the Methodist women's media revolution's impact on the rhetoric of Mary Wollstonecraft and Hester Anne Rogers. According to Winckles, Wollstonecraft's and Rogers's life writing revealed 'that religionspecifically mystical erotic religion-provided a language and a system of meaning which stood in stark contrast to male structures of religious meaning and power and which was largely outside of men's direct control" (140). To this phenomenon, misogynistic pundits such as the notorious poetaster Richard Polwhele responded by claiming that enthusiasm revealed sexual or gender disorders. Winckles persuasively argues that Polwhele's Unsex'd Females (1800) and similar texts recycle what had by the 1790s become conventional criticism of Methodism overall.

After Wesley's death (1791), Methodism cracked down on preaching by women and other aspects of women's agency within the movement. In 1803, Winckles points out, the Methodist conference officially discouraged women from preaching because, so they said, there are sufficient men preachers and some Methodists opposed women preaching (142). Hardly a strong argument, this rationale seems notable for its lack of . . . enthusiasm. From within the fold, some women fought back. Winckles examines the manuscript "Letterbook" of Methodist preacher Sarah Crosby at Duke University's Frank Baker Collection of Wesleyana and British Methodism, demonstrating "how women used manuscript production and circulation practices in order to forward a narrative about their lives and work that was missing from mainstream Methodist contexts" (147). Winckles also explains how archaic curatorial policy obscure the women of the Methodist archive (147). Notably, Crosby transcribes Mary Bosanquet Fletcher 
arguing for women's preaching (51). Crosby and Fletcher conversed epistolarily in terms critical of John Wesley himself, and they intended their private but circulated correspondence as a new kind of public writing (151-2). I would even propose that they joined the revolution in popular writing identified by critics such as Ian Haywood in his The Revolution in Popular Literature: Print, Politics and the People, 1790-1860 (2004). Many of the Methodist women writers who populate Winckles's study were the wives of middle- or working-class men. The aforementioned Boyce was a tailor's wife. Evidently a good place to look for literature by eighteenth-century working-class women is the Methodist manuscript archive.

In fact, as Winckles's final substantial chapter proves, what Methodism fostered, in spite of its later intentions, was a complex women's literary network that included obscure working-class women such as Boyce and also literary luminaries recognizable from the Romantic canon later established in the late nineteenth and early twentieth centuries. This chapter traces Sally Wesley's network, identifying a coterie of "Evangelical Bluestockings" who revolted against Methodist and establishment "regulation of enthusiasm" (177). As Winckles's prose and a clarifying chart of the Romantic-era Methodist social network shows, "literary friendships" and familial bonds interlinked Elizabeth de Quincey (mother of Thomas), with Theodosia Blachford (mother of Mary Tighe), as well as other recognizable figures. This chapter follows up brilliantly on the point of Winckles's editorship of the volume Women's Literary Networks and Romanticism: "A Tribe of Authoresses" (2018): that women authors of the Romantic era were hardly isolated, nor even limited to kinship coteries, but participated in and shaped social, professional, and literary networks in ways scholars have largely disregarded, perhaps envisioning such women confined to anachronistically nuclear or patriarchal domestic spheres. While the mainstream Methodism of the nineteenth century slowed down the Methodist media revolution, Winckles's rigor and enthusiasm revives it. 